\title{
PENGARUH TINGKAT PENDAPATAN DAN PENGELOLAAN DANA ZAKAT TERHADAP KEPATUHAN MASYARAKAT MEMBAYAR ZAKAT DI KABUPATEN BIREUEN
}

\author{
Murhaban $^{1}$, Merawati $^{2}$ \\ ${ }^{1,2}$ Prodi Akuntansi Fakultas Ekonomi dan Bisnis Universitas Malikussaleh Lhokseumawe \\ murhaban@unimal.ac.id
}

\begin{abstract}
This study aims to determine the effect of the income level and management of zakat funds on the community compliance to pay zakat in Bireuen Regency. The sampling technique used is probability sampling technique with the number of respondents as many as 62 people. The data used in this study is in the form of primary data in the form of questionnaires. The analytical method used is multiple linear regression analysis with the help of SPSS program. The results of this study indicate that the level of income has a significant effect on the community compliance to pay zakat in Bireuen Regencyt and the management of zakat funds has no significant effect on the community compliance to pay zakat in Bireuen Regency.
\end{abstract}

Keywords: Income Level, Management of Zakat Funds, and Community Compliance to Pay Zakat.

\section{PENDAHULUAN}

Indonesia merupakan negara yang dominannya berkependudukan beragama Islam. Banyaknya penduduk Indonesia yang beragama Islam menyebabkan semakin banyak masyarakat Muslim yang menjalankan syari'ah Islam dalam kehidupan sosial ekonomi. Indonesia, dengan populasi penduduk Muslim mencapai $87,21 \%$ pada tahun 2013 (Kemenag, 2013) diyakini memiliki potensi zakat yang besar. Indonesia merupakan salah satu negara dengan potensi zakat yang cukup besar.

$\begin{array}{ll}\text { Potensi Zakat semakin mengalami } \\ \text { peningkatan } & \text { pertumbuhan }\end{array}$ diungkapkan oleh Murniati (2013) "Berdasarkan studi yang dilakukan Badan Amil Zakat Nasional (BAZNAS) dengan Institut Pertanian Bogor dan Islamic Development pada tahun 2011, potensi zakat Nasional mencapai angka Rp.217,3 trilliun per tahun. Meskipun realisasi zakat masih dibawah satu persen dari proyeksi, namun pertumbuhan zakat nasional terus menunjukkan pertumbuhan yang signifikan".

Potensi perolehan zakat di Indonesia sebenarnya cukup besar, akan tetapi belum bisa dimaksimalkan sebagaimana diungkapkan oleh Canggih, et. al (2017): "Dari total penduduk di Indonesia, diasumsikan yang wajib membayar zakat maal adalah angkatan kerja beragama Islam yang sedang bekerja. Rata-rata sekitar 39\% dari total penduduk Indonesia, wajib membayar zakat maal. Jika pendapatan perkapita penduduk Indonesia pada tahun 2015 sejumlah $\mathrm{Rp}$ 31,360.300,- maka potensi perolehan zakat seharusnya mencapai Rp 82.609.152.671.724. Perolehan zakat pada tahun 2015 perolehan zakat mencapai Rp 74.225.748.204,- atau kurang dari 1 $\%$ dari potensi zakat yang ada".

Ketimpangan antara potensi zakat dan realisasi zakat yang diterima bertolak belakang dengan fakta bahwa Indonesia merupakan negara dengan penduduk Muslim terbesar di dunia, dengan hampir $87.5 \%$ penduduk Muslim. Ketimpangan antara potensi dan realisasi zakat berkisar pada $0.06 \%$ pada tahun $2011,0.068 \%$ pada tahun 2012 , $0.075 \%$ pada tahun $2013,0.089 \%$ pada tahun 2014 , dan $0,09 \%$ pada tahun 2015 . Zakat adalah bagian perekonomian Indonesia yang membutuhkan pengembangan dan strukturisasi. Dana zakat harus dapat dikelola lebih baik oleh sistem organisasi zakat yang seharusnya ditingkatkan kinerjanya.

Dalam mewujudkan pemerataan pendapatan ekonomi masyarakat serta terciptanya pengelolaan dana zakat dengan baik maka diperlukan keaktifan lembaga-lembaga pengelola zakat (amil) dengan tujuan meningkatkan pelayanan terhadap masyarakat dalam menunaikan zakat, meningkatkan fungsi dan peran pranata agama dalam mewujudkan kesejahteraan masyarakat dan keadilan sosial serta meningkatkan hasil dan daya guna zakat. Di Indonesia, pengelolaan dana zakat, infaq dan shadaqah telah diatur Undang-Undang Nomor 23 Tahun 2011 tentang Pengelolaan Zakat. Undang-undang ini mengatur Organisasi Pengelola Zakat (OPZ) yang boleh beroperasi di Indonesia. Organisasi Pengelola Zakat yang disebutkan dalam Undang-Undang tersebut adalah Badan Amil Zakat (BAZ) dan Lembaga Amil Zakat (LAZ).

Pengelolaan zakat diatur berdasarkan Undang-Undang No. 23 Tahun 2011 yang berisi pedoman teknis pengelolaan zakat yang meliputi kegiatan perencanaan, pengorganisasian, 
pelaksanaan, dan pengawasan terhadap pengumpulan dan pendistribusian, serta pendayagunaan zakat. Dalam undang-undang tersebut disebutkan dua tujuan dari pengelolaan zakat. Pertama, meningkatkan efektivitas dan efisiensi pelayanan dalam pengelolaan zakat. Kedua, meningkatkan manfaat zakat untuk mewujudkan kesejahteraan masyarakat dan penanggulangan kemiskinan. Kedua tujuan tersebut akan tercapai apabila sistem distribusi zakat, infaq dan shadaqah yang digunakan sesuai dengan kebutuhan mustahik.

Mukhlis dan Beik (2013) menyebutkan: "bahwa mayoritas penduduk Muslim di Indonesia masih enggan dan kurang termotivasi untuk membayar zakat, terutama zakat maal. Minimnya minat muzakki untuk menyalurkan zakat profesi ke lembaga pengelola zakat menjadi penyebab kesenjangan antara besaran potensi zakat dan nominal zakat yang diterima". Menurut Hafiduddin (2011) menyebutkan: "profesionalisme lembaga amil zakat dan hasil pengelolaan zakat yang tidak terpublikasi kepada masyarakat luas adalah hal yang membuat kepercayaan masyarakat rendah terhadap lembaga pengelola zakat". Hal ini menunjukkan kepatuhan masyarakat dalam membayar zakat berbanding lurus dengan peran dari lembaga zakat.

Qanun Aceh Nomor 10 Tahun 2010 menyebutkan: "Baitul Mal merupakan sebuah lembaga keuangan syariah yang mengelola keuangan masyarakat dan menggunakan prinsipprinsip syariah dalam sistim pengelolaan keuangannya. Baitul Mal Kabupaten Bireuen merupakan Lembaga Daerah non Struktural yang diberi kewenangan untuk mengelola zakat, infaq, shadaqah, harta wakaf, harta agama lainnya untuk kemaslahatan umat, dan menjadi wali/ wali pengawas terhadap anak yatim piatu dan hartanya, serta pengelolaan terhadap harta warisan yang tidak ada wali berdasarkan Syariat Islam”.

Kehadiran Baitul Mal Kabupaten Bireuen adalah untuk mengkoordinir zakat masyarakat secara keseluruhan, baik instansi pemerintah/swasta maupun lainnya dengan cara melakukan pendataan para muzakki dan mustahiq sehingga Baitul Mal dapat menambah sumber pengelolaannya dan pendistribusian zakat akan lebih tepat sasaran. Pengelolaan zakat oleh Baitul Mal Kabupaten Bireuen merupakan sebagian dari ajaran Islam yang dapat membantu pembangunan ekonomi daerah.

Salah satu potensi zakat di Kabupaten Bireuen adalah zakat di kalangan pengusaha, dikarenakan Kabupaten

Bireuen merupakan Kabupaten yang terletak di jalan lintas provinsi yang mempunyai berbagai macam aktivitas bisnis. Mulai dari bisnis kelas bawah, kelas menengah hingga bisnis kelas atas. Akan tetapi realita yang terjadi dilapangan jauh berbeda, justru potensi zakat terbesar yang di kutip oleh Baitul Mal Kabupaten Bireuen adalah zakat profesi di kalangan Pegawai Negeri Sipil (PNS). Berdasarkan kajian dokumentasi terhadap data-data pengumpulan zakat di Baitul Mal Kabupaten Bireuen. Hal itu tentu saja di dasari oleh berbagai macam faktor, baik faktor yang berasal dari kalangan pengusaha sendiri, maupun faktor kepercayaan masyarakat terhadap Baitul Mal Kabupaten Bireuen. Maka peneliti tertarik untuk meneliti tingkat pendapatan pegawai negri sipil (PNS) dan pengelolaan dana zakat, apakah berpengaruh pada kepatuhan dalam membayar zakat.

Selama tahun 2012-2016 dana zakat yang diterima oleh Baitul Mal Kabupaten Bireuen selalu mengalami kenaikan dengan nilai yang cukup besar. Terjadi peningkatan besar pada tahun 2016 jika dibandingkan dengan penerimaan zakat pada tahun 2012. Berdasarkan tabel 1.1 dibawah maka dapat dilihat bahwa pada tahun 2012 penerimaan Zakat adalah 1.100.656.000, kemudian pada tahun 2013 sebesar 1.759.363.195, pada tahun 2014 sebesar 2.051.096.618, di tahun 2015 sebesar 3.069.661.000, dan pada tahun 2016 mengalami kenaikan pula sebesar 4.069.967.000. setiap tahun mengalami kenaikan dalam penerimaan zakat, hal ini mungkin dikarenakan ada perencanaan dan pengembangan yang telah dilaksanakan oleh pihak Baitul Mal Bireuen dalam megusahakan.

Tabel 1

Data Penerimaan Dana Zakat oleh Baitul Mal Kabupaten Bireuen Tahun 2012-2016

\begin{tabular}{|c|c|c|c|c|}
\hline \multirow{2}{*}{$\begin{array}{c}\text { N } \\
\mathbf{o}\end{array}$} & $\begin{array}{c}\text { Tah } \\
\mathbf{u n}\end{array}$ & $\begin{array}{c}\text { Zakal } \\
\text { Mal }\end{array}$ & Infaq & $\begin{array}{c}\text { Total } \\
\text { Penerima } \\
\text { an }\end{array}$ \\
\cline { 3 - 5 } 1 & 2012 & $\begin{array}{c}1.100 .656 \\
.000\end{array}$ & $\begin{array}{c}2.095 .193 \\
.000\end{array}$ & $\begin{array}{c}3.195 .849 . \\
000\end{array}$ \\
\hline 2 & 2013 & $\begin{array}{c}1.759 .363 \\
.195\end{array}$ & $\begin{array}{c}2.952 .892 \\
.662\end{array}$ & $\begin{array}{c}4.712 .255 . \\
857\end{array}$ \\
\hline 3 & 2014 & $\begin{array}{c}2.051 .096 \\
.618\end{array}$ & $\begin{array}{c}3.911 .785 \\
.370\end{array}$ & $\begin{array}{c}5.962 .881 . \\
988\end{array}$ \\
\hline 4 & 2015 & $\begin{array}{c}3.069 .661 \\
.000\end{array}$ & $\begin{array}{c}4.174 .436 \\
.000\end{array}$ & $\begin{array}{c}7.244 .097 . \\
000\end{array}$ \\
\hline 5 & 2016 & $\begin{array}{c}4.069 .967 \\
.000\end{array}$ & 6.016 .668 & 10.082 .635 \\
.000 & .000 \\
\hline
\end{tabular}


Sumber : Baitul Mal Bireuen 2017

Meskipun nilai penerimaan zakat mengalami peningkatan yang signifikan, pihak Baitul Mal masih mengalami beberapa kendala dalam menghimpun dana zakat, masih terdapat instansi yang belum membayarkan zakat kepada Baitul Mal. Sebenarnya menyalurkan zakat profesi bukan paksaan namun kesadaran masing-masing individu yang wajib berzakat. Sebaigamana pemotongan gaji PNS oleh Bendahara gaji, yang demikian disalurkan kepada pihak yang mengelola zakat dan disalurkan kepada mustahiq dengan professional dan transparan guna untuk meningkatkan kepercayaan muzzaki dalam berzakat.

Dalam beberapa tahun terakhir, konsep zakat mengalami revolusi dan kini dianggap sebagai salah satu sumber penting pembangunan ekonomi Islam, yang berfungsi sebagai sumber pendapatan finansial untuk membangun ekonomi masyarakat Muslim. Dengan demikian, setiap individu Muslim wajib untuk membayar zakat, guna mendukung peran zakat dalam pengembangan ekonomi Islam. Secara umum, umat Islam menaruh perhatian serius pada kewajiban membayar zakat fitrah, karena zakat ini merupakan kewajiban yang zakat mudah dipenuhi serta telah lama dikaitkan dengan praktik tradisi di bulan Ramadhan). Akan tetapi, masyarakat seolah kurang perhatian terhadap zakat kekayaan yang jumlahnya jauh lebih besar. Zakat kekayaan dapat dibagi lagi menjadi zakat untuk pendapatan/pekerjaan, bisnis, tabungan, tanaman pangan dan pertanian, emas dan perak, saham dan sumber daya alam. Zakat pendapatan dari usaha bekerja seseorang dibayar berdasarkan gaji yang diterima sementara zakat pada bisnis dibayar berdasarkan keuntungan yang diterima sepanjang tahun.

Oleh karena itu, zakat merupakan salah satu Ibadah pokok dalam Islam yang dalam pelaksanaannya merupakan pemberian wajib yang dikenakan pada kekayaan seseorang yang telah memenuhi syarat-syarat tertentu. Dengan demikian, perintah membayar zakat adalah sesuatu yang bersifat pasti dan tidak dapat ditawar-tawar. Perintah menunaikan zakat atas harta dan penghasilan yang diperoleh, mendidik umat Islam agar menjauhi sifat mementingkan diri sendiri, dan sebaliknya mewujudkan semangat berbagi dengan orang lain.

Menurut Canggih, et.al, (2017) mengatakan bahwa: "Zakat adalah bentuk ibadah yang berfungsi sebagai alat pemerataan pendapatan dalam masyarakat untuk mengurangi kesenjangan antara orang yang berkecukupan dengan orang yang kekurangan. Zakat dapat memperkecil ketimpangan ekonomi masyarakat". Pengelolaan zakat yang tepat diharapkan dapat mewujudkan distribusi kekayaan yang merata. Menurut pernyataan standar akuntansi keuangan syariah PSAK No. 109, Zakat adalah harta yang wajib dikeluarkan oleh muzakki seuai dengan ketentuan syari'ah untuk diberikan kepada yang berhak menerimanya (mustahiq). Nur Farhana et al (2016) menjelaskan bahwa: "faktor yang mempengaruhi minat muzakki dalam membayar zakat, yakni faktor intrinsik dan faktor ektrinsik. Faktor intrinsik diantaranya adalah religiusitas, pendidikan, kepercayaan dan pendapatan. Sedangkan faktor ekstrinsik seperti kepuasan, reputasi dan layanan".

Permasalahan yang sering muncul ditengah masyarakat kita adalah kepada siapa zakat harus diberikan. Lebih utama disalurkan langsung oleh muzzaki kepada mustahiq, atau sebaliknya melalui amil zakat. Jika disalurkan kepada mustahiq, memang ada perasaan tenang karena menyaksikan secara langsung zakatnya tersebut telah disalurkan kepada mereka yang dianggap berhak menerimanya. Tapi terkadang penyaluran langsung yang dilakukan oleh muzzaki tidak mengenai sasaran yang tepat.Terkadang muzzaki merasa sudah menyalurkan zakat kepada mustahik sebagaimana diungkapkan oleh Kanji, et.al, (2011): padahal ternyata yang menerima bukan mustahiq yang sesungguhnya, hanya karena kedekatan emosi maka ia memberikan zakat kepadanya. Misalnya disalurkan kepada kerabatnya sendiri, yang menurut anggapannya sudah temasuk kategori mustahiq, padahal jika dibandingkan dengan orang yang berada dilingkungan sekitarnya, masih banyak orang-orang yang lebih berhak untuk menerimanya sebab lebih fakir, lebih miskin, dan lebih menderita dibanding dengan kerabatnya tersebut".

Kesadaran berzakat dipandang indikator utama ketundukan seseorang pada ajaran Islam. Mengenai zakat harta, Alquran dan hadist hanya menyebutkan secara eksplisit tujuh jenis harta benda yang wajib dikeluarkan zakatnya beserta keterangan tentang batas minimal harta yang wajib dizakati (nisab) dan jatuh tempo zakatnya (haul),yaitu emas, perak, hasil tanaman dan buahbuahan, barang dagangan, ternak, hasil tambang dan barang temuan. Berbeda dengan zaman modern sekarang ini kehidupan masyarakat sudah berkembang ke hal lain, dan bahkan perkembangan ekonomi modern sulit diukur dengan apa yang terjadi di zaman awal Islam, karena zakat bersifat dinamis terutama tentang materi zakatnya. Dengan demikian maka ketentuan zakat mengalami 
perkembangan secara terus-menerus sesuai dengan perkembangan kehidupan dan perekonomian zaman modern.

Salah satu bentuk terobosan hukum yang harus dilakukan dalam bidang zakat ini adalah dengan mengembangkan hukum zakat itu sendiri yang salah satunya adalah menjadikan penghasilan profesi sebagai salah satu hal yang wajib dikeluarkan zakatnya, sebab penghasilan profesi adalah salah satu sumber mata pencaharian umat manusia yang sangat potensial di zaman modern.

Zakat profesi yaitu zakat yang wajib dikeluarkan dari penghasilan dari profesi-profesi tertentu yang ditekuni, seperti pegawai negeri, dokter, pengacara, dan sebagainya. Karena kewajiban zakat atas gaji pengawai negeri/dosen adalah kewajiban ijtihadi. Maka yang dibangun adalah kesadaran dari setiap pegawai negeri bahwa zakat itu memiliki tujuan yang sangat mulia. Selain sebagai pembersih jiwa dan harta, juga memiliki fungsi sosial yang sangat dalam, agar harta itu tidak hanya beredar di kalangan orang-orang kaya saja.

Dalam kenyataan di masyarakat atau pegawai masih banyak orang-orang yang memiliki kekayaan dan penghasilan besar tidak mengerti atau tidak menyadari bahwa sesungguhnya mereka adalah muzzaki. Selain itu, kalaupun mereka menyadari kewajibannya untuk membayar zakat, mereka tidak tahu atau tidak mengerti bagaimana mencatat atau menghitung secara benar kekayaan dan penghasilan yang wajib dizakati itu. Pada satu sisi ada masyarakat atau pegawai yang belum sadar zakat, namun pada sisi lain ada masyarakat atau pegawai yang sadar membayar zakat tapi tidak percaya pada badan atau lembaga pengelola zakat. Oleh karena itu, sejalan dengan upaya memperluas pemahaman dan wawasan masyarakat atau pegawai tentang fikih dan manajemen zakat, maka menjadi tugas Pemerintah dan para ahli ekonomi untuk membuat dan mensosialisasikan konsep operasionalisasi zakat yang baku sebagai instrument pengaman sosial (social security).

Keputusan seseorang dalam membayar zakat profesi sering pula dipengaruhi oleh kondisi keuangannya. Pada beberapa penelitian menunjukkan bahwa kondisi keuangan seseorang dan kewajiban keluarganya dapat memoderasi hubungan komitmen dan kinerja seseorang. Sebagian Masyarakat beranggapan bahwa zakat profesi dikenakan hanya pada masyarakat mapan saja menjadi alasan untuk tidak patuh dalam memba yar zakat. Anggapan ini berdampak pada penundaan atau justru merasa enggan membayarkan zakat profesinya. Jika setiap muslim memiliki tingkat kepatuhan yang tinggi terhadap zakat, maka potensi zakat yang besar seharusnya dapat terserap. Kemudian, Potensi zakat yang terserap dapat terdistribusikan secara optimal. Sehingga manfaat dari pembayaran zakat dapat terasa pada setiap muslim.

Lembaga zakat harus menggunakan pembukuan yang benar dan siap di audit oleh akuntan publik, jika Lembaga Zakat belum menerapkan akuntansi zakat. Akibatnya, ada masalah dalam audit laporan keuangan Badan Amil Zakat tersebut. Padahal, audit merupakan salah satu hal penting untuk meningkatkan kepercayaan masyarakat terhadap lembaga pengelola zakat. Sehingga pengeluaran dana yang dilakukan dapat di pertanggung jawabkan baik kepada umat maupun kepada Allah SWT. Kualitas laporan keuangan organisasi pengelola zakat sangat dipengaruhi oleh seberapa bagus sistem akuntansi yang digunakan. Standarisasi laporan keuangan yang ditetapkan organisasi pengelola zakat harus sesuai dengan standar Akuntansi Indonesia (IAI) yang telah mengesahkan peraturan standar dalam hal ini, yaitu Pernyataan Standar Akuntansi Keuangan Syariah No. 109 (PSAK 109) tentang Akuntansi Zakat, dan Infaq. Pernyataan ini disusun dengan tujuan untuk mengatur pengakuan, pengukuran, penyajian, dan pengungkapan transaksi zakat dan shadakah. Berlakunya standar ini memudahkan bagi semua organisasi zakat dalam meningkatkan efektifitas dan efisiensi dalam pengelolaan zakatnya. Dengan dikeluarkannya pernyataan ini seluruh organisasi pengelola zakat di Indonesia sekarang wajib untuk menggunakannya.

Adapun rumusan masalah dalam penelitian ini adalah: 1. Apakah terdapat pengaruh tingkat pendapatan terhadap kepatuhan masyarakat membayar zakat di Kabupaten Bireuen. 2. Apakah terdapat pengaruh pengelolaan dana zakat terhadap kepatuhan masyarakat membayar zakat di Kabupaten Bireuen. 3. Apakah terdapat pengaruh tingkat pendapatan dan pengelolaan dana zakat terhadap kepatuhan masyarakat membayar zakat di Kabupaten Bireuen.

\section{TINJAUAN PUSTAKA}

\section{TINGKAT PENDAPATAN}

Menurut Rizal (2001:13) dalam Damanhur dan Nurainiah (2013) menyatakan bahwa "setiap kegiatan seseorang mengharapkan imbalan atau pendapatan, pendapatan yang dimaksud disini adalah pendapatan yang diterima dari hasil kerja dan hasil usaha yang dilakukan secara maksimal dalam suatu pekerjaan”. Selanjutnya Harahap 
(2002) menyatakan bahwa "pendapatan merupakan sebagai hasil dari penjualan barang atau pemberian jasa yang dibebankan kepada langganan, atau mereka yang menerima jasa".

"Pendapatan ialah tambahan harta yang diperoleh dari sumber yang diketahui dan bersifat tetap. Sumber pendapatan dapat bersifat material, seperti tanah atau non material seperti pekerjaan atau bisa dari keduanya. Sehingga pendapatan terbagi atas kekayaan juga mewajibkan zakat atas pendapatan. Contohnya kewajiban zakat atas pendapatan hasil pertanian, hasil barang tambang, dan juga pendapatan dari hasil pekerjaan bebas, termasuk didalamnya gaji/ upah, honorarium dan hasil-hasil lain yang diperoleh dari berbagai pekerjaan dan usaha (Qardawi, 2004: 1033-1035, dalam 'Aisyah).

Pendapatan (income) menurut PSAK 23 peningkatan manfaat ekonomi selama satu periode akuntansi tertentu dalam bentuk pemasukan atau penambahan aktiva atau penurunan kewajiban yang menyebabkan kenaikan ekuitas, yang tidak berasal dari konstribusi penanaman modal. Berdasarkan beberapa pengertian tersebut dapat disimpulkan bahwa pendapatan merupakan penghasilan atau output sejumlah uang yang didapatkan dari usaha seseorang dalam berkerja keras.

\section{PENGELOLA ZAKAT}

Pada masa awal Islam, yakni Rasulullah SAW, dan para sahabat prinsip-prinsip Islam telah dilaksanakan secara demonstratif, terutama dalam hal zakat yang merupakan rukun Islam ketiga setelah syahadat dan shalat. Secara nyata, zakat telah menghasilkan perubahan ekonomi yang menyeluruh dalam masyarakat Muslim ('Aisyah, 2014).

Ibrahim dalam Muhammad (2002:34-36) mengungkapkan bahwa citra baik mengenai pengumpulan zakat semasa kehidupan Rasulullah dilakukan dengan cara mengumpulkan zakat perorangan dan membentuk panitia pengumpulan zakat. Rasulullah juga memerintahkan kepada para pejabat bagaimana berperilaku dan mempermudah urusan masyarakat. Pengelola zakat berkerja baik dan tidak serakah hanya mengutamakan kepentingan diri dengan melupakan kepentingan fakir miskin ('Aisyah, 2014).

Menurut pasal 1 ayat 2 Undang Undang Nomor 23 tahun 2011. Zakat adalah suatu kegiatan perencanaan, pelaksanaan, dan pengawasan terhadap pengumpulan dan pendistribusian zakat. Sedangkan Organisasi Pengelola Zakat adalah organisasi yang bergerak di bidang pengelolaan zakat, infaq, maupun sedekah. Di Indonesia sendiri zakat di kelola oleh 2 lembaga yakni Badan Amil Zakat yang pengelolaan di urus oleh Pemerintah dan yang kedua adalah Lembaga Amil Zakat yang pengelolaanya di urus oleh masyarakat.

\section{Badan Amil Zakat}

Berdasarkan pasal 1 Keputusan Menteri Agama Nomor 581 tahun 1999. Mendefinisikan Badan Amil Zakat adalah organisasi pengelola zakat yang dibentuk Pemerintah terdiri atas unsur masyarakat dan Pemerintah dengan tugas mengumpulkan, mendistribusikan, dan mendayagunakan zakat sesuai ketentuan agama. Baitul Mal Kabupaten Bireuen merupakan Lembaga Daerah non Struktural yang diberi kewenangan untuk mengelola zakat, infaq, shadaqah, harta wakaf, harta agama lainnya untuk kemaslahatan umat, dan menjadi wali/ wali pengawas terhadap anak yatim piatu dan hartanya, serta pengelolaan terhadap harta warisan yang tidak ada wali berdasarkan Syariat Islam (Qanun Aceh Nomor 10 Tahun 2010).

Pada tahun 2003 Pemerintah Kabupaten Bireuen membentuk Badan Amil Zakat, Infaq dan Shadaqah (BAZIS) Kabupaten Bireuen dengan Keputusan Bupati Bireuen Nomor 365 Tahun 2003 Tanggal 11 Desember 2003, dengan Ketua Badan Pelaksana Tgk. H. M. Yusuf A. Wahab, Lc, (Pimpinan Dayah Babussalam Jeunieb) dan dilengkapi dengan Dewan Pengawas yang diketuai oleh Tgk. H. Hasanoel Bashry HG (Waled Hasaneol Samalanga). BAZIS tersebut merupakan cikal bakal terbentuknya Badan Baitul Mal Kabupaten Bireuen. Periode selanjutnya Badan Baitul Mal Kabupaten Bireuen ditetapkan dengan Keputusan Bupati Bireuen Nomor 74 Tahun 2006 Tanggal 8 Maret 2006.

\section{ZAKAT}

Ditinjau dari segi bahasa, kata zakat mempunyai beberapa arti, yaitu al-barakatu 'keberkahan', al-namaa 'pertumbuhan dan perkembangan', al-thaharatu ' kesucian' dan ashshalahu 'keberesan'. Makna lain kata zaka' sebagaimana digunakan dalam Al-Qur'an adalah suci dari dosa. Sedangkan menurut istilah syara', zakat memiliki dua makna tersebut karena dengan mengeluarkan zakat menjadi sebab timbulnya berkah dan bersihnya pada harta. Seperti yang dinyatakan dalam sebuah hadist, "Tidak berkurang harta karena sedekah (dikeluarkan zakatnya)".

Sedangkan menurut Qardawi (2005:34) di dalam Damanhur dan Nurainiah (2013) ditinjau dari segi bahasa (etimologi) kata zakat merupakan kata dasar dari zakat yag berarti suci, berkah, 
tumbuh, dan terpuji. Sedangkan dari segi istilah fiqih, zakat berarti sejumlah harta tertentu yang diwajibkan Allah diserahkan kepada orang yang berhak menerimanya, disamping berarti mengeluarkan jumlah tertentu itu sendiri.

Secara terminologi syariah zakat merujuk pada aktivitas memberikan sebagian kekayaan dalam jumlah dan perhitungan tertentu untuk orang-orang tertentu sebagaimana ditentukan (Sari, 2006:21 dalam Damanhur dan Nurainiah, 2013). Menurut Mazhap Hanafi zakat didefinisikan dengan menjadikan sebagian harta yang khusus sebagai milik orang yang khusus, yang ditentukan oleh syari'at karena Allah (Zuhaily, 2000 dalam Damanhur dan Nurainiah, 2013). Menurut Undang-Undang No. 23 Tahun 2011 tentang Pengelolaan Zakat, harta benda yang wajib dikeluarkan zakatnya, meliputi: emas, perak, dan logam mulia lainnya; uang dan surat berharga lainnya, pendapatan, jasa, dan rikaz (barang temuan). Apabila kekayaan seorang muslim tidak memenuhi salah satu ketentuan, misalnya nishab, maka kekayaan tersebut belum wajib dikeluarkan zakatnya.

\section{LANDASAN HUKUM ZAKAT}

Zakat merupakan kewajiban untuk mengeluarkan sebagian harta yang bersifat mengikat dan bukan anjuran. Kewajiban tersebut berlaku untuk seluruh umat Islam yang baligh atau belum, berakal atau gila. Dimana mereka sudah memiliki sejumlah harta yang sudah masuk batas nisabnya, maka wajib dikeluarkan harta dalam jumlah tertentu untuk diberikan kepada mustahiq zakat yang terdiri dari delapan golongan. Landasan kewajiban zakat disebutkan dalam Al-Qur'an dan Al-Hadist.

a. Al-Qur'an

Didalam Al-Qur'an Allah SWT telah menyebutkan tentang zakat, diantaranya dalam Surat Al-Baqarah ayat 43: "Dan dirikanlah shalat, tunaikanlah zakat dan ruku'lah beserta orang-orang yang ruku" Surat At-Taubah ayat 103: "Ambillah zakat dari sebagian harta mereka, dengan zakat itu kamu membersihkan dan mensucikan mereka dan mendo'alah untuk mereka. Sesungguhnya do'a kamu itu (menjadi) ketentraman jiwa bagi mereka, dan Allah Maha Mendengar lagi Maha Mengetahui"”.

b. Hadist

Hadist Rasulullah SWA menyatakan: Artinya: "Islam adalah engkau beribadah kepada Allah dan tidak menyekutukanNya, mendirikan shalat, menunaikan zakat yang di fardhukan, dan berpuasa di bulan Ramadhan."(HR. Bukhari).
Kemudian dalam hadist yang lain juga dijelaskan, ketika Rasulullah SAW mengutus mu'adz bin jabal ke daerah yaman. Beliau bersabda kepadanya:"..jika mereka menuruti perintahmu untuk itu, ketetapan atas mereka untuk mengeluarkan zakat yang diambil dari orang-orang kaya dan diberikan lagi kepada orang-orang fakir diantara mereka.."(HR. Bukhari).

\section{JENIS ZAKAT}

\section{Zakat Fitrah}

Zakat Fitrah adalah zakat pribadi yang diwajibkan atas diri setiap muslim yang memiliki syarat-syarat yang ditetapkan dan ditunaikan pada bulan Ramadhan sampai menjelang shalat sunnah Idul Fitri. Berakhirnya bulan Ramadhan itu menjadi sebab lahiriah pada kewajiban zakat tersebut sehingga diberi nama zakat Fitri atau Zakat Fitrah. Adapun fungsi dari zakat fitrah adalah untuk mengembalikan manusia muslim kepada fitrahya dengan cara mensucikan jiwanya. Kadar zakat fitrah yang dikeluarkan sebanyak satu sha'. Satu sha' adalah empat mud sedangkan satu mud adalah $0,6 \mathrm{~kg}$. Jadi satu sha' adalah sebanding dengan 2,4 $\mathrm{kg}$, maka dibulatkan menjadi $2,5 \mathrm{~kg}$. Adapun jenis makanan yang wajib dikeluarkan zakatnya sebagai alat pembayaran zakat fitrah adalah tepung, terigu, kurma, gandum, kismis dan aqit. Untuk daerah atau negara yang makanan pokoknya selain dari lima makanan tersebut, Mazhab Syafi'i dan Maliki membolehkan membayar zakat dengan makanan pokok yang lain seperti beras, jagung, sagu dan ubi.

\section{Zakat Mal}

Selain zakat fitrah terdapat juga zakat maal atau zakat harta yang perhitungannya didasarkan pada harta atau pendapatan yang diperoleh seseorang. Menurut bahasa harta adalah sesuatu yang ingin sekali dimiliki oleh manusia, untuk dimanfaatkan dan untuk menyimpannya. Sedangkan secara syariat harta merupakan sesuatu yang dikuasai dan dapat digunakan secara lazim. Perbedaan antara zakat fitrah dan zakat maal adalah zakat fitrah pokok persoalan yang harus dizakati adalah diri atau jiwa bagi seorang muslim beserta diri orang lain yang menjadi tanggungannya, sedangkan zakat maal persolan pokoknya terletak pada pemilikan harat kekayaan yang batasan dan segala ketentuannya diatur berdasarkan syariat berdasarkan dalil Al-Quran dan Sunnah. Adapun macam-macam harta yang wajib dikeluarkan zakatnya adalah zakat hasil pertanian (tanamantanaman atau buah-buahan), zakat hewan ternak, 
zakat emas dan perak, zakat barang dagangan, zakat barang temuan, zakat barang tambang dan zakat profesi.

\section{KEPATUHAN}

Menurut Muhammad Murtadha dalam Juliana Nasution (2011), kata patuh berarti alinqiyad artinya ketundukan. Menurut Ali AlJurjani, taat atau patuh adalah muwafaqah alamrthau'an artinya menyesuaikan diri dengan perintah secara tunduk. Menurut Green, kepatuhan merupakan suatu perubahan perilaku dari perilaku yang tidak menaati peraturan ke perilaku yang menaati peraturan.

Bentuk dan perwujudan kepatuhan merupakan penggambaran dari perilaku muzakki dalam membayar zakat, yang banyak di pengaruhi oleh tingkat keyakinan, pemahaman, kecenderungan dan minat yang dimiliki oleh muzzaki. Menurut Bachmid, dkk (2012)" kesadaran membayar zakat sesuai dengan ketentuan syari'at, seperti nishab, haul, serta cara mengeluarkannya secara benar (melalui amil) merupakan bentuk dan perwujudan kepatuhan muzzaki terhadap perintah zakat".

Pada dasarnya, faktor pendorong utama umat beragama menjalankan agamanya adalah faktor keimanan. Al-Maragi dalam Juliana Nasution (2011) "menegaskan orang yang benarbenar beriman adalah orang yang mematuhi semua perintah Allah, baik itu mudah atau sulit, disukai atau dienggani, meskipun dengan membunuh diri sendiri atau keluar dari kampung halaman". Terkait kepatuhan membayar zakat, penelitian Ahmad Mukhlis dan Irfan Syauqi Beik telah membuktikan bahwa faktor keimanan berpengaruh terhadap kepatuhan berzakat. Adapun faktor lainnya seperti penghargaan, altruisme, dan pengetahuan zakat juga merupakan faktor-faktor yang berpengaruh terhadap kepatuhan membayar zakat.

\section{KERANGKA KONSEPTUAL}

Menurut Sugiyono (2009:92) kerangka konseptual/ pemikiran merupakan penjelasan sementara terhadap gejala yang menjadi objek permasalahan dan juga merupakan sintesa tentang hubungan variabel yang disusun dari berbagai teori yang telah dideskripsikan yang membuahkan kesimpulan yang berupa hipotesis.kerangka konseptual dalam penelitian ini digambarkan seperti di bawah ini.

Gambar 2 Kerangka Konseptual

Tingkat Pendapatan (X1)

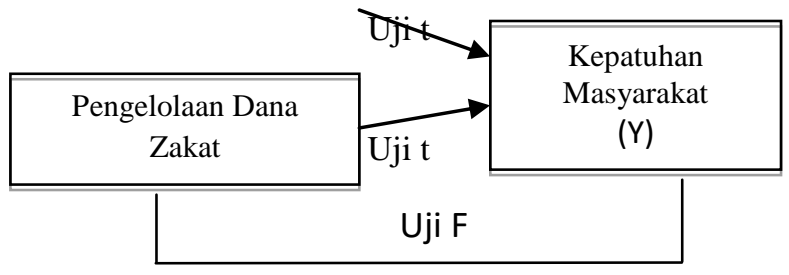

\section{HIPOTESIS}

Menurut Sugiyono (2009:96) hipotesis merupakan jawaban sementara terhadap rumusan masalah penelitian, di mana rumusan masalah penelitian telah dinyatakan dalam bentuk pertanyaan. Dikatakan sementara karena jawaban yang diberikan baru didasarkan pada teori. Hipotesis dirumuskan atas dasar kerangka pikir yang merupakan jawaban sementara atas masalah yang dirumuskan.

H1 : Tingkat Pendapatan berpengaruh terhadap kepatuhan masyarakat membayar zakat di Kabupaten Bireuen.

H2 : Pengelolaan Dana Zakat berpengaruh terhadap Kepatuhan Masyarakat Membayar Zakat di Kabupaten Bireuen.

H3 :Tingkat Pendapatan dan Pengelolaan Dana Zakat berpengaruh terhadap kepatuhan masyarakat membayar Zakat di Kabupaten Bireuen.

\section{METODE PENELITIAN}

Populasi dalam penelitian ini adalah Pegawai Negeri Sipil (PNS) yang berada di wilayah Kabupaten Bireuen yang berjumlah 170 orang.

Pengambilan sampel dalam penelitian ini dengan teknik probability sampling. Menurut Sugiyono (2010:63), Probability sampling adalah teknik pengambilan sampel yang memberikan peluang yang sama bagi setiap unsur (anggota) populasi untuk dipilih menjadi anggota sampel.

Agar memperoleh sampel yang representatif dari populasi, maka setiap subjek dalam populasi diupayakan untuk memiliki peluang yang sama untuk menjadi sampel. Adapun rumusan yang digunakan untuk mengukur sampel, digunakan rumus Slovin dalam Husein Umar (2010:146) yaitu ukuran sampel yang merupakan perbandingan dari populasi dengan presentasi kelonggaran ketidaktelitian, karena dalam pengambilan sampel dapat ditolerir atau diinginkan. Dalam pengambilan sampel ini digunakan taraf $10 \%$, dan dalam menentukan ukuran sampel (n) dan populasi (N) yang telah ditetapkan. Rumus Slovin untuk menentukan sampel adalah sebagai berikut : 


$$
n=\frac{\mathrm{N}}{1+\mathrm{Ne}^{2}}
$$

Keterangan:

n : Ukuran sampel

N: Ukuran Populasi

e : Persen kelonggaran ketidaktelitian karena kesalahan pengambilan sampel

yang masih dapat ditolerir (tingkat kesalahan yang diambil sebesar $10 \%=0,1)$.

Berdasarkan rumus diatas maka jumlah sampel $\mathrm{n}=\frac{N}{1+\mathrm{Ne}^{2}}$ dalam penelitian ini adalah:

$=\frac{170}{1+(170)(0,1)^{2}}=\frac{170}{1+1,7}=\frac{170}{2,7}=62,9$

Dari hasil rumus diatas maka dapat disimpulkan bahwa dari seluruh populasi yang berjumlah 170 Pegawai Negeri Sipil hanya 62 sampel yang digunakan dalam penelitian ini. Hal ini dilakukan untuk mempermudah dalam pengolahan data dan untuk hasil pengujian yang lebih baik. Sampel yang diambil berdasarkan teknik probability sampilng; simple random sampling, dimana peneliti memberikan peluang yang sama bagi setiap anggota pupulasi untuk dipilih menjadi sampel yang dilakukan secara acak tanpa memperhatikan strata yang ada dalam populasi itu sendiri.

Pengambilan sampel ini dilakukan dengan teknik insindental, seperti yang dikemukakan Sugiyono (2012:122), bahwa sampling insindental adalah penentuan sampel berdasarkan kebetulan, yaitu siapa saja yang secara kebetulan/'insindental bertemu dengan peneliti maka dapat digunakan sebagai sampel, bila dipandang orang yang kebetulan ditemui itu cocok sebagai sumber data.

Sumber data dari penelitian ini adalah data primer dengan cara membagikan kuesioner kepada wajib pajak Pegawai Negeri Sipil (PNS) yang berada di wilayah Kabupaten Bireuen. Kuesioner yang tersebar sebanyak 62. Metode analisis yang digunakan adalah analisis regresi linier berganda dengan rumus:

$$
\begin{aligned}
& Y=\boldsymbol{\alpha}+\boldsymbol{\beta}_{\mathbf{1}} \mathbf{X}_{\mathbf{1}}+\boldsymbol{\beta}_{\mathbf{2}} \mathbf{X}_{\mathbf{2}}+\mathbf{e} \\
& \mathrm{Y}=\text { Kepatuhan masyarakat } \\
& \alpha=\text { Konstanta } \\
& \beta_{1}=\text { Koefesien tingkat pendapatan } \\
& \beta_{2}=\text { Koefisien pengelolaan dana } \\
& \text { zakat } \\
& \mathrm{X}_{1}=\text { Variabel tingkat pendapatan } \\
& \mathrm{X}_{2}=\text { Variabel pengelolaan dana } \\
& \text { zakat } \\
& \mathrm{e}=\text { error }
\end{aligned}
$$

\section{DEFINISI OPERASIONAL PENGUKURAN VARIABEL \\ Tingkat Pendapatan $\left(\mathrm{X}_{1}\right)$}

Tingkat pendapatan ialah tambahan harta yang diperoleh dari sumber yang diketahui dan bersifat tetap atau hasil maupun penerimaan yang diterima dalam suatu pekerjaan. Tingkat pendapatan dipengaruhi oleh tinggi rendahnya jabatan, keuletan serta kerja kerasnya dalam melakukan suatu pekerjaan. Semakin tinggi jabatannya semakin besar pendapatan. Maka semakin tinggi penghasilannya akan terkena kewajiban membayar zakat, namun jika penghasilan yang didapat tidak mencapai nisab zakat, maka bisa diganti dengan membayar infak ataupun shadaqah.

\section{Pengelolaan Dana Zakat $\left(\mathbf{X}_{2}\right)$}

Organisasi Pengelola Zakat adalah organisasi yang bergerak di bidang pengelolaan zakat, infaq, maupun sedekah. Pengelola zakat berkerja baik dan tidak serakah hanya mengutamakan kepentingan diri dengan melupakan kepentingan fakir miskin. Organisasi pengelola zakat merupakan faktor dominan yang berpengaruh terhadap kepatuhan berzakat, meliputi pelayanan yang cepat dan akurat, pengelolaan yang baik, memberikan informasi yang jelas dan terpercaya, trasparansi dalam laporan keuangan, sistem pembayaran yang mudah serta profesionalitas amil.

\section{Kepatuhan Masyarakat Membayar Zakat}

Kepatuhan merupakan suatu perubahan perilaku dari perilaku yang tidak menaati peraturan ke perilaku yang menaati peraturan. Kepatuhan merupakan penggambaran dari perilaku muzakki dalam membayar zakat, yang banyak di pengaruhi oleh tingkat keyakinan, pemahaman, kecenderungan dan minat yang dimiliki oleh muzakki. Menurut Bachmid, dkk (2012), kesadaran membayar zakat sesuai dengan ketentuan syari'at, seperti nishab, haul, serta cara mengeluarkannya secara benar (melalui amil) merupakan bentuk dan perwujudan kepatuhan muzakki terhadap perintah zakat. Kepatuhan artinya orang yang selalu patuh membayar zakat tepat pada waktunya baik dalam segi apapun tingkat pendapatan atau penghasilan yang telah memenuhi persyaratan untuk berzakat.

\section{Skala Pengukuran Variabel}

Pengukuran variabel ini menggunakan indikator yang dikembangkan oleh Djaali (2008:28) aspek pengukuran terhadap data yang di analisis dilakukan dengan pembentukan indikator pada setiap pernyataan yang diajukan dengan 
menggunakan skala likert (liker scale) yang merupakan skala interval dimana setiap pertanyaan mempunyai interval jawaban antara 1 (sangat tidak setuju) dan 5 (sangat setuju). Instrumen variabel $\left(\mathrm{X}_{1}, \mathrm{X}_{2}\right.$, dan $\left.\mathrm{Y}\right)$ masing-masing terdiri dari 10 item pernyatan yang diukur dengan 5 poin skala likert, yaitu Sangat Setuju (5), Setuju (4), Netral (3), Tidak Setuju (2), Sangat Tidak Setuju (1).

\section{HASIL PENELITIAN DAN PEMBAHASAN}

\section{Gambaran Umum Responden}

Data dalam penelitian ini diperoleh dari penyebaran kuesioner kepada 62 orang responden yaitu pegawai Negri SIpil yang berada di wilayah Kabupaten Bireuen. Untuk menghitung data tersebut penulis penggunakan alat bantu Statistical Package for Social Science (SPSS). Dengan menggunakan SPSS, langkah pertama yang dilakukan adalah menghitung frekuensi dari pada karakteristik responden yang terdiri dari jenis kelamin, umur, pendidikan terakhir dan golongan dan pendapatan. responden berdasarkan jenis kelamin terbanyak yaitu Perempuan sebanyak 32 orang atau sebesar $52 \%$, pria sebanyak 30 orang atau sebesar $48 \%$ dari seluruh responden penelitian. jumlah responden berdasarkan umurnya antara 2030 tahun sebanyak 0 orang atau sebesar $0 \%$, yang berumur antara 31-40 tahun sebanyak 25 orang atau sebesar 40\%, yang berumur 41-50 tahun sebanyak 22 orang atau sebesar $36 \%$, yang berumur antara 51-60 tahun sebanyak 10 orang atau sebesar $16 \%$, dan yang berumur $>60$ tahun sebanyak 5 orang atau sebesar $8 \%$. responden berdasarkan jenjang pendidikan terakhir tersebar pada pendidikan SLTA sebanyak 15 orang atau sebesar $24 \%$, dan responden yang memiliki pendidikan Sarjana sebanyak 47 orang atau sebesar $76 \%$. responden berdasarkan pendapatan yaitu Rp. 2.500 .000 - Rp. 5.000 .000 sebanyak 45 orang atau sebesar $73 \%$, yang pendapatan Rp. 6.000.000 - Rp. 10.000.000 sebanyak 10 orang atau sebesar 16, dan yang pendapatan Rp. $>10.000 .000$ sebanyak 7 orang atau sebesar $11 \%$.

\section{HASIL PENGUJIAN KUALITAS DATA Hasil Uji Validitas}

Hasil pengujian validitas menunjukkan bahwa seluruh indikator independent dan dependent menghasilkan faktor corrected Item-Total Correlation $>0,226$ dimana indikator variabel Tingkat pendapatan dilambangkan dengan $\mathrm{X}_{1}$ indikatornya $\mathrm{X}_{1} .1, \mathrm{X}_{1} .2, \mathrm{X}_{1} .3, \mathrm{X}_{1}, 4, \mathrm{X}_{1}, 5 \mathrm{X}_{1} .6$, $X_{1} .7, X_{1} .8, X_{1}, 9, X_{1}, 10$. Variabel Pengelola dana zakat dilambangkan dengan $X_{2}$ indikatornya $X_{2} .1$,
$X_{2} .2, X_{2} .3, X_{2} .4, X_{2} .5, X_{2} .6, X_{2} .7, X_{2} .8, X_{2} .9$, $\mathrm{X}_{2} .10$. dan Variabel Kepat dilambanguhan pembayaran dengan $\mathrm{Y}$ dengan indikatornya $\mathrm{Y}_{1} .1$, $\mathrm{Y}_{1} .2, \mathrm{Y}_{1} .3 \mathrm{Y}_{1 .} 4, \mathrm{Y} \mathrm{Y}_{1} .5, \mathrm{Y}_{1} .6, \mathrm{Y}_{1} .7 \mathrm{Y}_{1} .8, \mathrm{Y}_{1} .9, \mathrm{Y}_{1} .10$.

Dari hasil yang didapat oleh peneliti melakukan dengan menggunakan aplikasi SPSS, pada variabel $\mathrm{X}_{1}$ (Tingkat pendapatan) dimana $\mathrm{X}_{1} .1$ didapatkan pearson correlation sebesar 0,523, untuk $\mathrm{X}_{1} .2$ didapatkan pearson correlation sebesar 0,389 , untuk $\mathrm{X}_{1} .3$ didapatkan pearson correlation sebesar 0,385, untuk $\mathrm{X}_{1} .4$ didapatkan pearson correlation sebesar 0,429 , untuk $\mathrm{X}_{1} .5$ didapatkan pearson correlation $0,544, \mathrm{X}_{1} .6$ didapatkan pearson correlation sebesar 0,355 , untuk $\mathrm{X}_{1} .7$ didapatkan pearson correlation sebesar 0,607, untuk $\mathrm{X}_{1} .8$ didapatkan pearson correlation sebesar 0,424, untuk $\mathrm{X}_{1} .9$ didapatkan pearson correlation sebesar 0,411 dan untuk $\mathrm{X}_{1} .10$ didapatkan pearson correlation 0,469 .

Pada variabel $\mathrm{X}_{2}$ (Pengelola dana zakat) dimana $\mathrm{X}_{2} .1$ didapatkan pearson correlation sebesar 0,535, untuk $\mathrm{X}_{2} .2$ didapatkan pearson correlation sebesar 0,439 , untuk $\mathrm{X}_{2} .3$ didapatkan pearson correlation sebesar 0,656 , dan untuk $\mathrm{X}_{2} \cdot 4$ didapatkan pearson correlation sebesar $0,499, \mathrm{X}_{2} .5$ didapatkan pearson correlation sebesar 0,467 , untuk $\mathrm{X}_{2} .6$ didapatkan pearson correlation sebesar 0,370 , untuk $\mathrm{X}_{2} .7$ didapatkan pearson correlation sebesar 0,569, dan untuk $\mathrm{X}_{2} .8$ didapatkan pearson correlation sebesar $0,347, \mathrm{X}_{2} .9$ didapatkan pearson correlation sebesar 0,480 , dan untuk $\mathrm{X}_{2} .10$ didapatkan pearson correlation sebesar 0,613.

Pada variabel Y (Kepatuhan pembayaran zakat) dimana $\mathrm{Y}_{1}$ dengan pearson correlation sebesar $0,515, \mathrm{Y}_{2}$ dengan pearson correlation sebesar 0,207, $\mathrm{Y}_{3}$ dengan pearson correlation sebesar $0,362, \mathrm{Y}_{4}$ dengan pearson correlation sebesar $0,477, \mathrm{Y}_{5}$ dengan pearson correlation sebesar $0,218, \mathrm{Y}_{6}$ dengan pearson correlation sebesar $0,346, \mathrm{Y}_{7}$ dengan pearson correlation sebesar $0,262, \mathrm{Y}_{8}$ dengan pearson correlation sebesar $0,502, \mathrm{Y}_{9}$ dengan pearson correlation sebesar $0,523, \mathrm{Y}_{10}$ dengan pearson correlation sebesar 0,467. Dari hasil yang telah didapat dapat disimpulkan bahwa indikator independent dan dependent variable dinyatakan valid.

\section{Hasil Uji Reliabilitas}

Uji reliabilitas digunakan untuk mengukur suatu kuesioner yang merupakan indikator dari variabel. Suatu kuesioner dapat dikatakan reliabel atau handal apabila jawaban seseorang terhadap pernyataan adalah stabil atau konsisten dari waktu ke waktu. Suatu variabel dikatakan handal apabila nilai croanbach alpha $(\alpha)$ lebih besar dari 0,60. 
Namun apabila nilai croanbach alpha lebih kecil 0,60 maka kuesioner dianggap kurang handal sehingga apabila dilakukan penelitian ulang terhadap variabel-variabel tersebut pada waktu dan dimensi yang bebeda, kesimpulannya akan berbeda (Ghozali, 2011).

Tabel 2 Hasil Uji Reabilitas Reliability Statistics

\begin{tabular}{|r|l|}
\hline Cronbach's Alpha & N of Items \\
\hline .757 & \\
\hline
\end{tabular}

Sumber : Hasil Penelitian, data diolah 2018

Berdasarkan tabel diatas dapat dilihat bahwa nilai Cronbach Alpha untuk independent variable yaitu sebesar 0,757 dan jumlah indicator pada kuisioner setiap satu variabel X1 adalah sepuluh, variabel X2 sepuluh, dan variabel Y juga sepuluh maka jumlah keseluruhan indicator adalah 30 seperti pada $N$ of item. Maka dapat disimpulkan bahwa nilai Cronbach Alpha untuk independent variable yaitu sebesar $0,757>0,60$ maka variabel dikatakan handal. Dari hasil data yang diolah melalui SPSS dapat disimpulkan bahwa keseluruhan variabel yang diteliti reliabel.

\section{HASIL UJI ASUMSI KLASIK Hasil Uji Normalitas}

Uji normalitas bertujuan menguji apakah dalam model regresi, variabel pengganggu atau residual memiliki distribusi normal. Kita dapat melihat dari normal probability plot yang membandingkan distribusi kumulatif dengan distribusi normal. Distribusi normal membentuk suatu garis lurus diagonal, dan plotting data residual akan dibandingkan dengan garis diagonalnya. Jika data terdistribusi normal, maka

\begin{tabular}{|cc|c|c|}
\hline \multirow{2}{*}{ Model } & \multicolumn{2}{|c|}{ Collinearity Statistics } \\
\cline { 2 - 3 } & Tolerance & VIF \\
\hline 1 & $\begin{array}{c}\text { (Constant) } \\
\text { Tingkat } \\
\text { Pendapatan }\end{array}$ & .760 & 1.316 \\
& & \\
& $\begin{array}{c}\text { Pengelola } \\
\text { Zakat }\end{array}$ & .760 & 1.316 \\
\hline
\end{tabular}

garis yang menggambarkan data sebenarnya akan mengikuti garis normalnya (Ghozali, 2005).

\section{Gambar 2 Normal P.P Plototof Regression Standar} Normal P-P Plot of Regression Standardized Residual
Sumber : Hasil Penelitian, Data diolah.2018

Setelah melihat hasil Gambar 4.1 Normal P-Plot maka dapat disimpulkan bahwa model regresi memenuhi asumsi normalitas karena pada grafik normal P-Plot terlihat titik - titik mendekati garis diagonal dan menyebar disekitar garis diagonal dan menunjukkan hasil yang sangat signifikan.

\section{Uji Multikolinieritas}

Uji multikolinieritas bertujuan untuk menguji apakah model regresi ditemukan adanya hubungan yang kuat diantara variabel bebas (independent), apabila terjadi korelasi, Ghozali (2011). Model regresi yang baik seharusnya tidak terjadi korelasi diantara variabel independen. Jika variabel independen saling berkorelasi, maka variabel-variabel ini tidak ortogonal. Variabel ortogonal adalah variabel independen yang nilai korelasi antar sesama variabel independen sama dengan nol. Menurut Ghozali (2009) Uji Multikolinieritas bertujuan untuk menguji dalam model regresi ditemukan adanya korelasi antar variabel - variabel bebas. Uji ini dilakukan dengan melihat Tolerance dan Variance Inflation factor (VIF). Nilai Tolerance yang rendah sama dengan nilai VIF yang tinggi karena VIF $=1$ /Tolerance) .

Jika nilai tolerance atau nilai Variance inflaction Factor (VIF) > 10 berarti dapat disimpulkan adanya multikolinearitas. Namun sebaliknya jika hasil perhitungan nilai nilai tolerance atau nilai Variance inflaction Factor (VIF) < 10 maka dapat disimpulkan bahwa tidak terjadi multikolinearitas antar variabel independent.

\section{Tabel 3 Hasil Uji Multikolinearitas}

Sumber : Hasil Penelitian, data diolah 2018

Pada tabel 3 dapat disimpulkan bahwa nilai VIF untuk kedua variabel yaitu $<10$ untuk

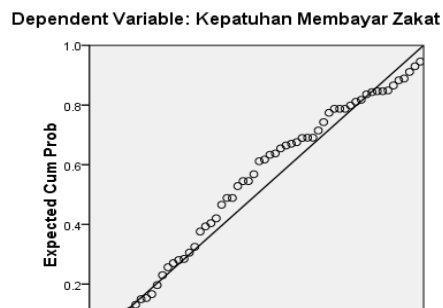


variabel $X_{1}$ (tingkat pendapatan) sebesar 1,316, nilai VIF untuk $\mathrm{X}_{2}$ (pengelola dana zakat) sebesar 1,316 . Sedangkan tolerance value untuk variabel tingkat pendapatan nilai tolerance-nya sebesar 0,760, dan variabel Pengelola zakat nilai tolerancenya sebesar 0,760. Jadi dapat disimpulkan bahwa tidak adanya multikolinieritas antar variabel yang diteliti.

\section{Uji Heteroskedastisitas}

Uji heteroskedastisitas bertujuan menguji apakah dalam model regresi terjadi ketidaksamaan varian dari residual satu pengamatan ke pengamatan yang lain. Jika varian dari residual satu pengamatan ke pengamatan lain tetap, maka disebut homoskedastisitas dan jika varian berbeda disebut heteroskedastisitas. Model regresi yang baik adalah yang homoskedastisitas atau tidak terjadi hiteroskedastisitas, Ghozali (2011). Deteksi ada atau tidaknya heteroskedastisitas dapat juga dilakukan dengan melihat ada tidaknya pola tertentu pada grafik plot scatterplot antara SRESID dan (ZPRED) dimana sumbu Y adalah Y yang telah diprediksi dan sumbu $\mathrm{X}$ adalah residual (Y prediksi-Y sesungguhnya) yang telah distudentized, Ghozali (2011). Untuk lebih jelasnya berikut adalah gambar dari hasil oleh data uji heteroskedastisitas :

\section{Gambar 3 Uji Heteroskedastisitas}

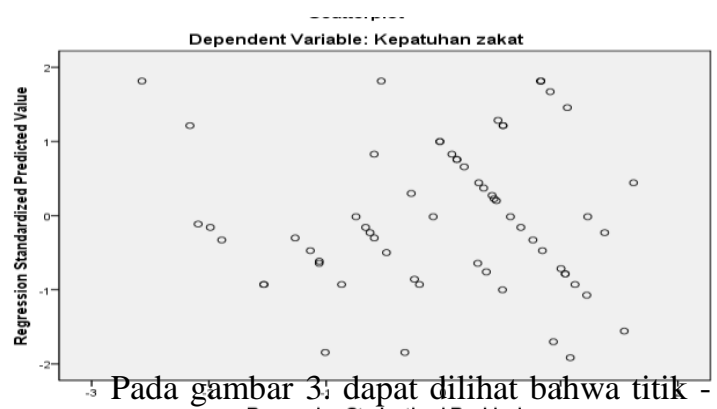

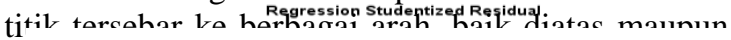
bi Sumber : Hasil Penelitian, data diolah 2018

mahwa tidak terjadi heteroskedastisitas pada model regresi.

\section{Hasil Analisis Regresi Linear Berganda}

Analisis data yang digunakan dalam penelitian ini adalah analisis kuantitatif dengan persamaan regresi linier berganda. Analisis kuantitatif yaitu analisis yang digunakan untuk menganalisa data yang diperoleh dari pernyataan yang memerlukan perhitungan statistik, sehingga analisis ini sering disebut dengan analisis statistik. Untuk menguji hipotesis pengaruh tingkat pendapatan $\left(\mathrm{X}_{1}\right)$, pengelola zakat $\left(\mathrm{X}_{2}\right)$, dan kepatuhan pembayaran zakat (Y).

Tabel 4 Metode Analisis Data

Coefficients $^{\mathrm{a}}$

\begin{tabular}{|c|c|c|c|c|c|}
\hline \multirow[t]{2}{*}{ Model } & \multicolumn{2}{|c|}{$\begin{array}{l}\text { Unstandardize } \\
\text { d Coefficients }\end{array}$} & $\begin{array}{l}\text { Standar } \\
\text { dized } \\
\text { Coeffici } \\
\text { ents }\end{array}$ & \multirow[t]{2}{*}{$\mathrm{t}$} & \multirow[t]{2}{*}{ Sig. } \\
\hline & B & $\begin{array}{l}\text { Std. } \\
\text { Error }\end{array}$ & Beta & & \\
\hline (Constant) & 2.818 & .431 & & $\begin{array}{c}6.54 \\
2\end{array}$ & .000 \\
\hline $\begin{array}{c}\text { Tingkat } \\
1 \text { Pendapata } \\
n\end{array}$ & .347 & .097 & .461 & $\begin{array}{c}3.59 \\
6\end{array}$ & .001 \\
\hline $\begin{array}{c}\text { Pengelola } \\
\text { Zakat }\end{array}$ & .065 & .088 & .094 & .731 & .468 \\
\hline
\end{tabular}

a. Dependent Variable: Kepatuhan Membayar Zakat_r

Sumber : Hasil Penelitian, data diolah 2018

Berdasarkan tabel 4.8 tersebut diperoleh persamaan regresi linear berganda sebagai berikut:

$$
\mathrm{Y}=2,818+0,347 \mathrm{X} 1+0,065 \mathrm{X} 2+\mathrm{e}
$$

Nilai konstanta $(\alpha)$ sebesar 2,818 hal ini berarti jika variabel tingkat pendapatan $\left(\mathrm{X}_{1}\right)$ dan Pengelola dana Zakat $\left(\mathrm{X}_{2}\right)$ yaitu variabel independen diasumsikan nol (0), maka besarnya kepatuhan membayar Zakat adalah sebesar 2,818\%. Nilai koefisien regresi tingkat pendapatan $\left(\mathrm{X}_{1}\right)$ sebesar 0,347 menyatakan, bahwa setiap perubahan variabel tingkat pendapatan $\left(\mathrm{X}_{1}\right)$ maka akan mempengaruhi kepatuhan membayar zakat sebesar $0,347 \%$ dengan asumsi variabel lain tetap. Nilai koefisien regresi Pengelola dana Zakat $\left(\mathrm{X}_{2}\right)$ sebesar 0,065 menyatakan, bahwa setiap perubahan variabel Pengelola dana Zakat $\left(\mathrm{X}_{2}\right)$ maka akan mempengaruhi kepatuhan membayar zakat sebesar $0,065 \%$ dengan asumsi variabel lain tetap. Standar error (e) merupakan variabel acak dan mempunyai distribusi probabilitas yang mewakili semua faktor yang mempunyai pengaruh terhadap $\mathrm{Y}$ tetapi tidak dimasukkan dalam persamaan. 


\section{Hasil Uji Parsial (Uji t)}

Tabel 5 Hasil Uji t

\begin{tabular}{|c|c|c|c|c|c|}
\hline \multirow[t]{2}{*}{ Model } & \multicolumn{2}{|c|}{$\begin{array}{l}\text { Unstandard } \\
\text { ized } \\
\text { Coefficient } \\
\text { s }\end{array}$} & \begin{tabular}{|c} 
Standar \\
dized \\
Coeffic \\
ients
\end{tabular} & \multirow[t]{2}{*}{$\mathrm{T}$} & \multirow[t]{2}{*}{ Sig. } \\
\hline & B & $\begin{array}{l}\text { Std. } \\
\text { Error }\end{array}$ & Beta & & \\
\hline (Constant) & $\begin{array}{c}2.81 \\
8\end{array}$ & .431 & & $\begin{array}{c}6 . \\
54 \\
2\end{array}$ & .000 \\
\hline $\begin{array}{c}\text { Tingkat } \\
\text { Pendapata } \\
\mathrm{n}\end{array}$ & .347 & .097 & .461 & $\begin{array}{c}3 . \\
59 \\
6\end{array}$ & .001 \\
\hline $\begin{array}{c}\text { Pengelola } \\
\text { Zakat }\end{array}$ & .065 & .088 & .094 & $\begin{array}{l}.7 \\
31\end{array}$ & .468 \\
\hline
\end{tabular}

Sumber : Hasil Penelitian, data diolah 2018

\section{Pengaruh Tingkat Pendapatan Terhadap Kepatuhan}

1. Jika $t_{\text {hitung }}>t_{\text {tabel }} H_{1}$ diterima, artinya tingkat pendapatan berpengaruh parsial terhadap kepatuhan masyarakat membayar zakat di Kabupaten Bireuen.

2. Jika $t_{\text {hitung }}<t_{\text {tabel }} H_{1}$ ditolak, artinya tingkat pendapatan tidak berpengaruh signifikan terhadap kepatuhan masyarakat membayar zakat di Kabupaten Bireuen.

Hasil perhitungan regresi menunjukkan bahwa hipotesis $\mathrm{H}_{1}$ diterima, hal ini berarti bahwa tingkat pendapatan $\left(\mathrm{X}_{1}\right)$ berpengaruh secara parsial terhadap kepatuhan masyarakat membayar zakat di Kabupaten Bireuen. Hal tersebut ditunjukkan dengan nilai $\mathrm{t}_{\text {hitung }}$ sebesar 3,596 dan lebih besar dari nilai $\mathrm{t}_{\text {tabel }} 2,001$ pada $\alpha=5 \%$ dan nilai signifikan sebesar $0,001<0,05$.

\section{Pengaruh Pengelola Dana Zakat Terhadap Kepatuhan}

1. Jika $t_{\text {hitung }}>t_{\text {tabel }} \mathrm{H}_{2}$ diterima, artinya pengelola dana zakat berpengaruh parsial terhadap kepatuhan masyarakat membayar zakat di Kabupaten Bireuen.

2. Jika $t_{\text {hitung }}<t_{\text {tabel }} \mathrm{H}_{2}$ ditolak, artinya pengelola dana zakat tidak berpengaruh signifikan terhadap kepatuhan masyarakat membayar zakat di Kabupaten Bireuen.

Hasil perhitungan regresi menunjukkan bahwa hipotesis $\mathrm{H}_{2}$ ditolak, hal ini berarti bahwa pengelola dana zakat $\left(\mathrm{X}_{2}\right)$ tidak berpengaruh secara parsial terhadap kepatuhan masyarakat membayar zakat di Kabupaten Bireuen. Hal tersebut ditunjukkan dengan nilai $t_{\text {hitung }}$ sebesar 0,731 dan lebih kecil dari nilai $t_{\text {tabel }} 2,001$ pada $\alpha=5 \%$ dan nilai signifikan sebesar 0,468 >0,05.

\section{Hasil Uji Simultan (Uji F)}

Tabel 6 Hasil Uji F

ANOVA $^{b}$

\begin{tabular}{|r|c|c|c|c|c|}
\hline Model & $\begin{array}{c}\text { Sum of } \\
\text { Squares }\end{array}$ & Df & $\begin{array}{c}\text { Mean } \\
\text { Square }\end{array}$ & F & Sig. \\
\hline $\begin{array}{r}\text { Regre } \\
\text { ssion }\end{array}$ & .495 & 2 & .247 & $\begin{array}{c}10.5 \\
62\end{array}$ & $.000^{\mathrm{a}}$ \\
& $\begin{array}{c}\text { Resid } \\
\text { ual }\end{array}$ & 1.382 & 59 & .023 & \\
& & & & \\
Total & 1.877 & 61 & & \\
\hline
\end{tabular}

a. Predictors: (Constant), Pengelola Zakat_r,

Tingkat Pendapatan_r

b. Dependent Variable: Kepatuhan zakat_r

Sumber : Hasil Penelitian, data diolah 2018

Berdasarkan tabel di atas hasil perhitungan yang diperoleh pada tabel diatas, nilai Fhitung sebesar 10.562 sedangkan nilai $\mathrm{F}_{\text {tabel }}$ pada $\mathrm{df}_{1}=2$ dan $\mathrm{df}_{2}=59$ pada $\alpha=0,05$ adalah sebesar 3,15 dengan tingkat signifikan sebesar 0,000 dapat diketahui bahwa nilai $F_{\text {hitung }}$ lebih besar dari nilai $\mathrm{F}_{\text {tabel }}(10,562>3,15)$, dan nilai signifikan $(\mathrm{sig})=$ 0,000 yang lebih kecil dari nilai $\alpha=0,05$. Hasil perhitungan regresi menunjukkan bahwa hipotesis $\mathrm{H}_{3}$ diterima. Maka dapat disimpulkan bahwa tingkat pendapatan $\left(\mathrm{X}_{1}\right)$, pengelola dana zakat $\left(\mathrm{X}_{2}\right)$, berpengaruh secara simultan terhadap kepatuhan masyarakat membayar zakat di Kabupaten Bireuen (Y).

\section{Koefisien Korelasi Dan Koefisien Determinasi}

Tabel 7 Hasil Uji Korelasi Model Summary ${ }^{b}$ 


\begin{tabular}{|c|c|c|c|c|}
\hline Model & $\mathrm{R}$ & $\begin{array}{l}\mathrm{R} \\
\text { Square }\end{array}$ & $\begin{array}{l}\text { Adjusted } \\
\text { r Square }\end{array}$ & $\begin{array}{l}\text { Std. } \\
\text { Error of } \\
\text { the } \\
\text { Estimate }\end{array}$ \\
\hline 1 & $.513^{\mathrm{a}}$ & .264 & .239 & .15305 \\
\hline
\end{tabular}

Sumber : Hasil Penelitian, data diolah 2018

Hasil pengujian menunjukkan besarnya koefisien korelasi berganda (R). Koefisien determinasi ( $\mathrm{R}$ square), dan koefisien determinasi yang disesuaikan (Adjusted $R$ Square). Berdasarkan tabel model summary di atas diperoleh bahwa nilai koefisien korelasi berganda (R) sebesar 0,513. Ini menunjukkan bahwa variabel tingkat pendapatan, dan pengelolaan dana zakat terhadap kepatuhan masyarakat membayar zakat mempunyai hubungan sedang. Hasil pada table di atas juga menunjukkan bahwa nilai koefisien determinasi ( $\mathrm{R}$ Square) sebesar 0,264 dan nilai koefisien determinasi yang sudah disesuaikan (Adjust $R$ Square) adalah 0,239. Hal ini berarti 23,9\% variasi dari kepatuhan masyarakat membayar zakat dapat dijelaskan oleh variasi independen (tingkat pendapatan dan pengelolaan dana zakat). Sedangkan sisanya 76,1\% (100\%-23,9\%) dijelaskan oleh variabel lain yang tidak disertakan dalam penelitian ini

\section{PEMBAHASAN HASIL PENELITIAN}

1. Pengaruh Tingkat Pendapatan Terhadap Kepatuhan Masyarakat Membayar Zakat di Kabupaten Bireuen

Kewajiban berzakat atas harta kekayaan yang dimiliki dan juga mewajibkan zakat atas pendapatan. Misalnya kewajiban zakat atas pendapatan baik dari hasil pertanian maupun dari hasil pendapatan dari hasil pekerjaan bebas, termasuk di dalamnya gaji atau upah, honorarium dan hasil-hasil lain yang didapatkan dari berbagai pekerjaan dan usaha. Hasil penelitian yang penulis ambil dalam penelitian ini adalah hasil pendapatan gaji pegawai Negeri sipil.

Berdasarkan hasil hipotesis menunjukkan bahwa tingkat pendapatan berpengaruh terhadap kepatuhan masyarakat membayar zakat di Kabupaten Bireuen. Sehingga hipotesis ini diterima, hal ini selaras dengan penelitian yang dilakukan oleh Sehingga hepotesis ini diterima, hal ini selaras dengan penelitian yang dilakukan oleh Salmawati (2018) yang menyatakan bahwa tingkat pendapatan berpengaruh terhadap minat muzakki untuk membayar zakat di Baitul Mal Kota Banda
Aceh. Hasil ini juga mendukung penelitian yang dilakukan oleh Eri Yanti Nasution (2017) menyimpulkan bahwa faktor pendapatan mempengaruhi masyarakat untuk membayarkan zakat di lembaga BAZNAS.

Berdasarkan perhitungan tersebut, dapat disimpulkan bahwa semakin tinggi pengaruh tingkat pendapatan, maka semakin tinggi pula masyarakat membayar zakat. Hasil tersebut didukung dengan Peraturan Bupati Bireuen Nomor 20 tahun 2013 tentang Mekanisme Pengelolaan Zakat, Infaq, Shadaqah dan Harta Agama lainnya, dan juga termasuk kepada jenis Pendapatan atau penghasilan yang dikelola oleh Baitul Mal. Baitul Mal Kabupaten Bireuen berwenang mengelola: Zakat Penghasilan dari PNS/ Pejabat/ Karyawan yang beragama Islam dalam Kabupaten Bireuen yag pembayarannya melalui APBK/ APBN dan sumber dana lainnya, Zakat Mal yang berasal dari BUMN, BUMD, Badan Hukum, Pengusaha, Pedagang serta profesi lainnya yang beroperasi/ beraktivitas dalam kabupaten Bireuen, Infaq, shadaqah dan Harta Agama lainnya dalam lingkup Kabupaten Bireuen.

Hasil penelitian ini tidak mendukung penelitian Muhammad Amirullah (2015) maka berarti pendapatan muzakki secara parsial tidak berpengaruh positif signifikan terhadap perilaku membayar zakat. Variabel pendapatan tidak mempunyai andil dalam perilaku membayar zakat untuk mengeluarkan zakat dalam batas nishabnya. Temuan ini terbukti dengan diketahui bahwa sebagian besar responden berpendapatan kecukupan serta membayar zakat setiap bulan atau setiap mendapat hasil profesi. Hal ini berarti bahwa meskipun kondisi keuangan berkecukupan tetapi tidak mempengaruhi kepatuhannya dan tetap secara teratur membayar zakat profesi.

\section{Pengaruh Pengelolaan Dana Zakat Terhadap Kepatuhan Masyarakat Membayar Zakat}

Berdasarkan uji hipotesis pengelola dana zakat tidak berpengaruh terhadap kepatuhan masyarakat membayar zakat di Kabupaten Bireuen. Maka hal ini menunjukkan bahwa secara parsial tidak berpengaruh signifikan terhadap pengelolaan dana zakat terhadap kepatuhan masyarakat membayar zakat. Sehingga hipotesis kedua ditolak. Tetapi penelitian ini selaras dari hasil penelitian yang dilakukan oleh Aziz (2015) yang mana menyatakan bahwa pengelola dana zakat tidak memengaruhi minat membayar zakat profesi. 
Hasil penelitian ini tidak mendukung penelitian 'Aisyah (2014) yang hasilnya menyatakan bahwa kredibilitas organisasi pengelola zakat berpengaruh secara parsial terhadap minat membayar zakat pada lembaga amil zakat (LAZ) atau badan amil zakat (BAZ).

Berdasarkan perhitungan tersebut, dapat disimpulkan bahwa pengelola dana zakat tidak berhubungan secara parsial terhadap kepatuhan masyarakat membayar zakat di Kabupaten Bireuen. Faktor lain yang menyebabkan tidak berpengaruh signifikan terhadap kepatuhan zakat profesi adalah kebiasaan atau regulasi. Deskriptif responden memberikan gambaran bahwa jenis pekerjaan mayoritas merupakan Pegawai Negeri Sipil (PNS) yang umumnya membayarkan zakat profesinya karena himbauan pemerintah setempat.

Pengaruh pengelola zakat terhadap kepatuhan masyarakat membayar zakat dapat juga dijelaskan oleh hasil deskriptif responden. Berdasarkan deskriptif responden diketahui bahwa sebagian besar responden berpendidikan Sekolah Menengah Atas (SMA) dan Sarjana dan memiliki pemahaman tinggi yang dibuktikan dengan nilai masing-masing pernyataan untuk variabel pengelola dana zakat.

\section{Pengaruh Tingkat Pendapatan Dan \\ Pengelolaan Dana Zakat Terhadap \\ KepatuhanMasyarakat Membayar Zakat Di \\ Kabupaten Bireuen}

Berdasarkan hasil analisis statistik dalam penelitian ini menunjukkan bahwa tingkat pendapatan dan pengelolaan dana zakat berpengaruh secara simultan terhadap kepatuhan masyarakat membayar zakat di Kabupaten Bireuen. Dari hasil tolak ukur yang digunakan dalam penelitian ini menunjukkan bahwa masih ada variabel-variabel lain yang dapat mempengaruhi kepatuhan masyarakat membayar zakat. Seperti dalam penelitian Ahmad Mukhlis dan Irfan Syauqi Beik (2013) yang menggunakan Keimanan, Penghargaan, Altruisme, dan kepuasan diri sebagai salah satu faktor yang mempengaruhi kepatuhan membayar zakat. Penelitian lainnya adalah penelitian 'Aisyah (2014) yang menggunakan variabel pengetahuan zakat dan minat membayar zakat sebagai variabel independen yang tidak diteliti dalam penelitian ini.

\section{KESIMPULAN DAN SARAN}

\section{KESIMPULAN}

Berdasarkan hasil penelitian yang dilakukan, maka dapat diambil kesimpulan antara lain sebagai berikut.

1. Tingkat pendapatan terdapat pengaruh secara parsial dan signifikan terhadap kepatuhan masyarakat membayar zakat di Kabupaten Bireuen.

2. Pengelola dana zakat tidak terdapat pengaruh secara parsial terhadap kepatuhan masyarakat membayar zakat di Kabupaten Bireuen.

3. Berdasarkan hasil perhitungan secara simultan dan signifikan dapat diketahui bahwa artinya tingkat pendapatan dan pengelola dana zakat berpengaruh secara simultan terhadap kepatuhan masyarakat membayar zakat di Kabupaten Bireuen.

\section{SARAN}

Adapun saran-saran yang diharapkan dalam penelitian ini adalah sebagai berikut:

1. Bagi Badan Amil Zakat Kabupaten Bireuen sebaiknya terus meningkatkan alokasi dana zakat untuk kegiatan produktif dalam rangka membangun perekonomian mandiri dan kesejahteraan masyarakat kurang mampu serta turut membantu pemerintah dalam hal pengentasan kemiskinan. Kemudian daripada itu agar pemanfaatan dana zakat lebih maksimal maka sebaiknya perlu diadakan pelatihan secara berkala, serta pemantauan berupa laporan pertanggung jawaban atas modal yang diberikan berupa laporan keuangan agar lebih professional dalam menjalankan amanah ini.

2. Bagi yang menggunakan dana zakat produktif agar benar- benar untuk usaha dan serius dalam menekuni usahanya, dalam rangka meningkatkan taraf perekonomian, tidak digunakan untuk kegiatan konsumtif yang kurang bernilai dedikasi agar tujuan dana zakat produktif

3. Bagi peneliti selanjutnya diharapkan memperhatikan indikator-indikator lain yang belum dicantumkan oleh penulis dalam penelitian ini.

\section{KEPUSTAKAAN}

Aisyah. (2014). Pengaruh Pengetahuan Zakat, Tingkat Pendapatan dan Kredibilitas Organisasi Pengelola Zakat Terhadap Minat Membayar Zakat Pada Lembaga Amil Zakat (LAZ) atau Badan Amil 
Zakat (BAZ). Jurnal. Diakses November 2017

Amirullah, M. (2015). Pengaruh Pemahaman, Pendapatan dan Lingkungan Muzakki Terhadap Perilaku Membayar Zakat. Jurnal. Diakses November 2017

Arikunto, Suharsimi. (2002). Metodelogi Penelitian. Pustaka Sinar Harapan. Jakarta.

Azis Sukma (2015). Strategi Penghimpunan Dana Zakat Lima Lembaga Pengelola Zakat di Indonesia. Jurnal Syarikah ISSN 2442-4420 Volume 2 Nomor 1, Juni 2015

Baitul Mal Kabupaten Bireuen, Profil Baitul Mal Bireuen. Kabupaten Bireuen

Clarashinta Canggih, dkk. (2017). Inklusi Pembayaran Zakat. Jurnal Ekonomi dan Bisnis Islam, Vol. 3, No. 1, Januari-Juni 2017.

Damanhur dan Nurainiah. (2013). Analisis Pengaruh Bantuan Zakat Terhadap Tingkat Kesejahteraan Masyarakat Di Kabupaten Aceh Utara. Jurnal Visioner dan Strategis Volume 5, Nomor 1, Maret 2016. Hal. 83-96

Djaali. (2008). Skala Likert. Jakarta: Pustaka Utama.

Faisal, Attamimi. "Persepsi Masyarakat Muslim tentang Zakat di Kota Palu." Jurnal Hunafa, Vol. 5, N0. 3. April 2008. Hal. 377.

Fakultas Ekonomi. (2014). Buku Panduan Penulisan Skripsi\&LKP. FEBI Press. Universitas Malikussaleh.

Geofrey A. Jehle. "Zakat and Inequality: Some Evidence From Pakistan." Review of Income and Wealth, vol 40, no. 2, (Juni 1994), dalam Patmawati Hj Ibrahim, "Pembangunan Ekonomi Melalui Agihan Zakat: Tinjauan Empirikal." Jurnal Syariah, Vol. 17:2 (Desember 2008), hlm. 231.

Ghozali, Imam. (2006). Analisis Multivariate dengan Program SPSS. Universitas Diponegoro. Jakarta.

(2009). Aplikasi Analisis dengan

Program SPSS. Edisi 3. BP UNDIP. Semarang

Hafidhuddin, Didin. (2010). Peran Strategis Organisasi Zakat dalam Menguatkan Zakat di Dunia. Jurnal Al-Infaq, Vol. 2 No. 1, Maret 2011. Hal. 1-4.

Hansen dan Mowen. (2005). Management Accounting. Buku 2. Edisi ke 7. Salemba Empat: Jakarta.
Hasibuan, A. S. (2010). Zakat Profesi Dan Penerapan, (Pekanbaru: Kantor Wilayah Kementerian Agama Provinsi Riau, 2010). Hal. 13

Kanji, dkk. (2011). Faktor Determinasi Mottivasi Membayar Zakat. Jurnal.

http://www.pasca.unhas.ac.id. Diakses tanggal 15 Desember 2017

Mahmudi. (2010), Manajemen Kinerja Sektor Edisi Kedua. Yogyakarta: UPP STIM YKPN

Mukhlis, Ahmad dan Irfan Syauqi Beik. (2013). Analisis Faktor-faktor yang Memengaruhi Tingkat Kepatuhan Membayar Zakat. Jurnal al-Muzara'ah, Vol 1, No. 1, 2013. November 2017. Hal. 83-106

Mufid, Aryono. “Zakat Nasional 2012 Rp1,7

Triliun,"

http://www.solopos.com/2012/10/20/bazna s-zakat-nasional-2012-rp17-triliun$\underline{340659 /}$, Diakses November 2017.

Murniati, Rina dan Irfan Syauqi Beik. (2013). Pengaruh Zakat Terhadap Indeks Pembangunan Manusia dan Tingkat Kemiskinan Mustahik : Studi Kasus Pendayagunaan BAZNAS Kota Bogor. Jurnal Al-Muzara'ah, Vol. 2, No. 2. Hal. 131-145.

Nasim, Arim dan M. Rizky SR. (2014). Pengaruh Transparansi Laporan Keuangan, Pengelolaan Zakat, Dan Sikap Pengelola Terhadap Tingkat Kepercayaan Muzakki (Studi Kasus Pada Lembaga Amil Zakat Di Kota Bandung). Jurnal Riset Akuntansi dan Keuangan, 2 (3), 2014, 550-561

Nasution, Juliana. (2017). Analisis Pengaruh Kepatuhan Membayar Zakat Terhadap Keberkahan. Jurnal At-Tawassuth, Vol. 11, No. 2, 2017. Hal. 282-303 
